\title{
The Indicators of Potential Presuppositions in Malala's Speeches as the Nobel Peace Laureate
}

\author{
Sefty Hanida Fitriyani ${ }^{凶}$, Januarius Mujiyanto, Warsono Warsono \\ Universitas Negeri Semarang, Indonesia
}

\begin{abstract}
Article Info
Article History:

Recived 24 December

2020

Accepted 07 February

2021

Published 20 June

2021

Keywords: presuppositions, the indicators of potential presuppositions, speech.

Abstract

Presupposition means that people have their own beliefs before communicating with others (Yule, 1996). He defined the types of presuppositions into six; existential, factive, lexical, structural, counterfactual, and non-factive presuppositions. The study examined the existence of the indicators of potential presuppositions in Malala's speeches after winning the Nobel and its relation toward the educational field. This study employed a qualitative approach. Four of Malala's speeches were the data. The researcher used an instrument based on the theory of the indicators of potential presuppositions proposed by Yule (1996). As a result, the researcher found 34 potential presuppositions in Malala's four speeches; 14 existential, six factual, four lexical, six structural, two nonfactive, and two potential counterfactual presuppositions. Being aware of presuppositions will help both students and teachers be good communicators and create a communicative and effective teaching-learning process to achieve the goal. Theoretically, it expounds on the potential presupposition indicators as one of the linguistic expressions by considering the users of those forms in a communication. Pedagogically, it may contribute to the enrichment of educational material. Practically, it could give more ideas and references for further researchers.
\end{abstract}




\section{INTRODUCTION}

Language plays a crucial role in our life as we tend to express our thoughts, ideas, and emotion through language. Language is a standard facility when two persons do an act of communication (Mujiyanto, 2011). They may express their feelings, ideas, and desires through language, either spoken or written (Mutmainnah \& Sutopo, 2016). The way of understanding all the sentences in the communication is called pragmatics. However, speakers or writers usually design their linguistic messages based on assumptions of their hearers or readers. In this case, pragmatics has presupposition. As Yule (1996) stated, the presupposition is something the speaker assumes to be the case before making an utterance. It means people have their own beliefs before communicating with others. This also deals with the process of how listeners catch information alongside their personal interpretation.

A presupposition is a thing that is presupposed, while presupposes means to assume something real before it has been proved. A presupposition is another kind of pragmatic inference which seems to be based more closely on the actual linguistic structure of sentences yet is too sensitive to contextual factors. A presupposition happens when the speakers assume certain information that is already known by the listeners but not be stated. As a result, this is counted as what is communicated but not said. Presupposition can occur both in verbal or nonverbal language. The findings are revealed. Fitri et al. (2012), who investigated the presupposition in the movie Harry Potter and the Deathly Hallows, found that factive presupposition was used the most since the speakers dominantly delivered their feeling. While Febrian \& Ardi (2012) analyzed the presupposition in the novel version found that structural type used the most by the writer. Specifically, in spoken language, presuppositions may happen in a talk show, speech, radio broadcasting, and debate (Marbun et al., 2015).

Giving a speech with a particular duration will be completely different from the daily conversation with uncertain time. The speakers might not utter all the information and messages regarding the topic given during their speech. A study focusing on the indicators of potential presuppositions that might be used by Malala Yousafzai has been done by the researcher. At her young age, Malala has a powerful mind to voice the children and girls' right to education. In line with English language learning, the implication of potential presupposition indicators in English education also became the study's focus.

Some researchers have conducted previous studies related to the presuppositions analysis in spoken discourse. According to Dabbagh (2013), the study about presupposition in theatre aims to understand the workings of discourse in dramas. A presupposition is believed to play a powerful tool to manipulate. Khalili (2017) added that by studying presupposition in a movie, there would be an improvement of knowledge about the concept of language and even communication. Ulum et al. (2018) stated that one example of spoken language is political speech, and Liang \& Liu (2016) have analyzed the presupposition in political discourse, Hilary Clinton's first campaign speech. The result showed that the study of presupposition could bring massive voters and win the debate for being aware of presupposition triggers. Lately, Tyas et al. (2020) conducted a study of presupposition triggers of teacher talk in higher institutions. They found that several categories realize presupposition triggers. The present study investigated potential presupposition indicators in Malala's speeches and its implication in English education.

By studying pragmatic presupposition, the researcher intends to reveal how interlocutors should concern the literal meaning of the utterances and the context. The awareness toward potential presupposition indicators can become one of the communication strategies and help us be a good communicator.

\section{METHOD}

This research employed a qualitative research design. Here, the researcher applies a single case study. This study's subject is Malala 
Yousafzai, the youngest laureate of the Nobel Peace Prize in 2014. The purpose is to study the six types of potential presuppositions indicators used by Malala in her speeches.

This research's analysis units were phrases, clauses, and utterances produced by Malala for presupposition analysis. The indicators of potential presuppositions used were proposed by Yule (1996) with the help of pragmatic presupposition trigger classified by Karttunen's classification of presupposition triggers (n.d.) in Levinson (1983) and Geurts (1999). The researcher uses secondary data to observe; four video recordings of Malala's speeches uploaded on YouTube. The observer transcribed these videos, and the transcription will be analyzed according to its presuppositions' triggers. In the last, the findings will be floored through an explanation. In the end, the use of those indicators will lead to the relevance and its implication toward English education.

The methods of collecting the data in the study's six objectives are the same, namely documentation. The procedures are 1) determining videos of speeches on YouTube, and 2) transcribing the speeches. After transcribing the speeches as the source of data, the researcher steps below to get the data; 1) identifying the clause, 2) classifying the indicators of potential presuppositions owned by each type, and 3) interpreting.

\section{RESULTS AND DISCUSSIONS}

As mentioned earlier, this study classifies the indicators of potential presuppositions based on Yule's classification with the help of pragmatic presupposition trigger classified by Karttunen in Levinson (1983) and Geurts (1999). They are 1) definite noun phrase, 2) possessive constructions, 3) factive verbs, 4) factive phrases, 5) implicative verbs, 6) change of state verbs, 7) iterative, 8) WH-question constructions, 9) adverbial clauses, 10) non-restrictive relative clause, 11) verbs associated with non-factive, and 12) if-clause. From those indicators, 34 potential presuppositions were found in Malala's speeches, as table 1 shows.

\section{The Existence of the Indicators of Existential Presupposition in Malala's Speeches as the Nobel Peace Laureate}

Existential presupposition can be recognized by the existence of a definite noun phrase and possessive construction. Table 1 shows that there were 14 potential existential presuppositions from 2 existential presupposition indicators. Definite noun phrase indicators resulted in 4 potential presuppositions, while possessive construction indicators led to 10 potential presuppositions. The indicators of existential presupposition definite noun phrases have resulted in 4 potential existential presuppositions, while possessive construction led to 10 potential presuppositions. The selected excerpt of potential presupposition indicators on Malala's speeches indicated by ">>" to realize certain linguistic features described.

1) Definite Noun Phrase

I am very honored to be here and meet the honorable Prime Minister of Pakistan.

>> Pakistan has Prime Minister.

Malala said this utterance in the opening of her speech. She addressed some important people attending the event. Her utterance can be analyzed as:

I am very honored to be here and meet the honorable Prime Minister of Pakistan. $(=\mathrm{p})$

Pakistan has Prime Minister. $\quad(=q)$ $\mathrm{p}>\mathrm{q}$

This data was triggered by a definite noun phrase, "the honorable Prime Minister of Pakistan." By this, the listeners assumed that Pakistan has a prime minister. Through this presupposition, Malala showed her understanding of Pakistan's government system. It is necessary to know well Pakistan's government system for Malala since she is Pakistani. Here, the presupposition showed possession. 
Table 1 The potential presuppositions in Malala's four speeches as Nobel Peace Laureate

\begin{tabular}{|c|c|c|}
\hline Type & $\begin{array}{l}\text { Indicators of } \\
\text { Potential } \\
\text { Presuppositio } \\
\mathrm{n}\end{array}$ & $\begin{array}{l}\text { Potential } \\
\text { Presuppositio } \\
\mathrm{n}\end{array}$ \\
\hline \multirow{23}{*}{ Existential } & \multirow{8}{*}{$\begin{array}{l}\text { Definite } \\
\text { Noun } \\
\text { Phrases }\end{array}$} & Possession \\
\hline & & Introducing \\
\hline & & Proper \\
\hline & & Nouns \\
\hline & & Introducing \\
\hline & & Common \\
\hline & & Nouns \\
\hline & & $\begin{array}{l}\text { Describing } \\
\text { the Preceding } \\
\text { Nouns }\end{array}$ \\
\hline & \multirow{15}{*}{$\begin{array}{l}\text { Possessive } \\
\text { Construction } \\
\text { s }\end{array}$} & $\begin{array}{ll}\text { Kinship } & \text { or } \\
\text { mutual } & \\
\text { relation } & \end{array}$ \\
\hline & & Adversary \\
\hline & & Relationship \\
\hline & & Country- \\
\hline & & Citizen \\
\hline & & Relationship \\
\hline & & Activity \\
\hline & & Life and \\
\hline & & Identity \\
\hline & & Concrete \\
\hline & & Nouns \\
\hline & & Parts of Body \\
\hline & & State \\
\hline & & Quality \\
\hline & & Hope \\
\hline \multirow{7}{*}{ Factive } & \multirow{3}{*}{ Factive Verbs } & Activity \\
\hline & & Feeling \\
\hline & & Condition \\
\hline & \multirow{4}{*}{$\begin{array}{l}\text { Factive } \\
\text { Phrases }\end{array}$} & Situation \\
\hline & & (Place) \\
\hline & & Identity \\
\hline & & Activity \\
\hline \multirow{6}{*}{ Lexical } & Implicative & Intention \\
\hline & Verbs & \\
\hline & \multirow{4}{*}{$\begin{array}{l}\text { Change of } \\
\text { State Verbs }\end{array}$} & Initiation \\
\hline & & Adjustment \\
\hline & & Deterioration \\
\hline & & Progression \\
\hline
\end{tabular}

\begin{tabular}{|c|c|c|}
\hline & Iterative & Repetition \\
\hline \multirow{11}{*}{ Structural } & Wh-Question & Humanity \\
\hline & Construction & Issue \\
\hline & $\mathrm{s}$ & \\
\hline & \multirow{4}{*}{$\begin{array}{l}\text { Adverbial } \\
\text { Clauses }\end{array}$} & Location \\
\hline & & State \\
\hline & & Activity \\
\hline & & Identity \\
\hline & Non- & Defense \\
\hline & Restrictive & \\
\hline & Relative & \\
\hline & Clauses & \\
\hline \multirow{4}{*}{ Non-Factive } & \multirow{2}{*}{$\begin{array}{l}\text { Verbs } \\
\text { Associated }\end{array}$} & Activity \\
\hline & & State \\
\hline & with Non- & Condition \\
\hline & Factive & \\
\hline \multirow{3}{*}{$\begin{array}{l}\text { Counterfactu } \\
\text { al }\end{array}$} & \multirow{3}{*}{ If-Clause } & $\begin{array}{l}\text { Possibility in } \\
\text { the Future }\end{array}$ \\
\hline & & An Unlikely \\
\hline & & Situation \\
\hline
\end{tabular}

2) Possessive Construction I remember how $\underline{\boldsymbol{m} \boldsymbol{y} \text { Mom }}$ would put a ladder at the back of our house so that if anything happened, we could escape. >> Malala has a mother.

This data was uttered when Malala talked about her past, experience, and hard times. From her utterance, it can be analyzed as:

I remember how my Mom would put a ladder at the back of our house so that if anything happened, we could escape. $\quad(=p)$

Malala has a mother. $\quad(=q)$ $\mathrm{p}>\mathrm{q}$

This data was triggered by the possessive construction " $\underline{m y \text { Mom. }}$. By this, the listeners presupposed that Malala has a mother. This presupposition shows kinship (Malala and mother). Through this presupposition, Malala revealed that she and her family had to survive against violence and injustice in her land.

The most potential presupposition that happened is the existential presupposition. This condition could happen for Malala voiced about a social campaign based on the world's real problems. Using these indicators, Malala believed that the audience has the same referent as hers. Moreover, the speeches contained more 
actual descriptive, real facts, real things, and real information to stimulate the audiences' attention and to emphasize her ideas.

The Existence of the Indicators of Factive Presupposition in Malala's Speeches as the Nobel Peace Laureate

Factive verbs and phrases have been proposed as the indicators of potential factual presupposition by Yule (1996). He defined the factive phrase as an adjectival phrase. Also, the existence of factive verbs as the indicators of factive presupposition has been supported by Levinson (1983) and Hooper (1974; cited in Wyse, 2009). Hence, there were six factive potential presuppositions from 2 factive presupposition indicators, as table 1 shows.

3) Factive Verbs

We soon learned that a man had attacked Parliament Hill.

>> Parliament Hill was attacked by a man.

This utterance was stated when Malala told why she could not enter Canada on her first attempt in 2014. Her utterance can be analyzed as: We soon learned that a man had attacked Parliament Hill. $(=\mathrm{p})$

Parliament Hill was attacked by a man. $(=q)$ $\mathrm{p}>>\mathrm{q}$

This data is triggered by the factive verb "learned." By this, the listeners assume that Parliament Hill was attacked by a man. There was an incident or activity that happened with the existence of a factive verb. Through this presupposition, Malala conveyed that she kept herself updated on the issues, terror attacks.

4) Factive Phrase

I am very proud to announce that Farah Mohamed, a refugee who fled Uganda and came to Canada as a child, is Malala Fund's new CEO.

>> Farah Mohamed is the CEO of Malala's fund.

This data was uttered when Malala talked about how Canadians had contributed to refugees around the world. From her utterance, it can be analyzed as:

I am very proud to announce that Farah Mohamed, a refugee who fled Uganda and came to Canada as a child, is Malala Fund's new CEO. $(=\mathrm{p})$

Farah Mohamed is the CEO of Malala's fund. $(=q)$

$p>>q$

This data is triggered by the factive phrase "I am very proud." By this, the listeners assume that Farah Mohamed is the CEO of Malala's fund. Through this presupposition, Malala meant that she revealed the background and identity of Farah Mohamed

In the end, these presupposition indicators were mostly uttered when Malala meant to express her feelings or condition and to convey the real and factual information -they are about activity, conditions, location/place, and identity- which mostly based on her own experience or background. She added a sense of certainty to the proposition. Hence, this presupposition type is useful in a campaign speech to get the listeners into the sense. Furthermore, here, Malala did it.

The Existence of the Indicators of Lexical Presupposition in Malala's Speeches as the Nobel Peace Laureate

Based on Yule (1996), lexical presupposition can be recognized by the existence of lexical items. Levinson (1983) specifically described lexical presupposition indicators by applying implicative verbs, change of state verbs, and iterative. There were six potential lexical presuppositions from 3 lexical presupposition indicators in this study, as table 1 shows.

5) Implicative Verbs I cannot forget their days.

>> Malala intends to remove her terrible memory of children who out of school.

This utterance was stated when Malala recalled her memories of 57 children out of school and did not get a quality education. Her utterance can be analyzed as:

I cannot forget their days. $(=p)$

Malala intended to remove her bad memory of children who out of school. $\quad(=q)$

$p>>$

This data is triggered by the implicative verb "forget." By this, the listeners assume that Malala intended to remove her bad memory of 
children out of school. Through this presupposition, she showed that children's sufferings meant a lot to her. She has been in the shoes of those children who out of school. Thus, this issue matters a lot to Malala until she cannot erase those bad memories.

6) Change of State Verbs

Many thanks to Mr. Gordon Brown for all the work he has done and continues to do for education.

>> Mr. Gordon Brown has started the activity concerning education.

This data was uttered in the opening of Malala's speech. She addresses Mr. Gordon, who has been making efforts for education. Her utterance can be analyzed as:

Many thanks to Mr. Gordon Brown for all the work he has done and continues to do for education. $(=\mathrm{p})$

Mr. Gordon Brown has started the activity concerning education.

$\mathrm{p}>\mathrm{q}$

The change of state verb triggers this data "continues to." By this, the listeners assume that Mr. Gordon Brown has started the activity concerning education. Through this presupposition, Malala showed that she paid attention to those who have contributed to education issues.

7) Iterative

I am back here again to ask world leaders to invest more in education.

>> Malala has been in Oslo before the time she was speaking.

This utterance was stated when Malala confessed her frequency of visiting Oslo. Her utterance can be analyzed as:

I am back here again to ask world leaders to invest more in education.

Malala has been in Oslo before the time she was speaking.

$\mathrm{p}>\mathrm{q}$

This data is triggered by iterative "back again." By this, the listeners assumed that Malala has been in Oslo before the time she was speaking. Through this presupposition, Malala showed her persistence to spend her time fighting for children and girls' education. She did not mind to back and forth on behalf of children.
Those three lexical presuppositions' three indicators play an indispensable role in strengthening important information, making language more economical and vivid. By lexical presupposition, Malala could say simple sentences but has much meaning. The use of one form with its asserted meaning is conventionally interpreted with the presupposition that another meaning is understood.

\section{The Existence of the Indicators of Structural Presupposition in Malala's Speeches as the Nobel Peace Laureate}

Wh-question construction in English has been proposed as the indicator of potential structural presupposition by Yule (1999). However, Geurts (1999) also classified adverbial clauses and non-restrictive relative clauses into structural presupposition triggers. These indicators resulted in six potential presuppositions.

8) Wh-Question Constructions

Why do children have to suffer, become homeless, and become targets of wars?

$>>$ War should not target children.

This utterance was stated when Malala questioned herself why she, the children, and other girls suffered. Her utterance can be analyzed as:

Why do children have to suffer, become homeless, and become targets of wars? $\quad(=p)$ War should not target children. $\quad(=q)$ $\mathrm{p}>\mathrm{q}$

The appearance of the wh-question construction "why do ...become" triggers the data. By this, the listeners assumed that war should not target children. Through this presupposition, Malala showed her criticism toward countries that are at war and having conflicts. She verbalized it to make it clear and open the eyes of the audience.

9) Adverbial Clause

He shared the hatred of the man who attacked the Quebec City mosque in January, killing six people while they were at prayer

>> The victims were at prayer, Quebec City mosque. 
This data was spoken when Malala criticized an attacker who admitted that he shared the same belief as Malala. From her utterance, it can be analyzed as:

He shared the hatred of the man who attacked the Quebec City mosque in January, killing six people while they were at prayer $\quad(=\mathrm{p})$

The victims were at prayer, Quebec City mosque. $(=q)$

$$
\mathrm{p}>\mathrm{q}
$$

This data is triggered by adverbial clauses of time "while." By this, the listeners assumed that the victims were at prayer, Quebec City mosque. Through this presupposition, Malala emphasized that she was exactly aware of the total number of dead victims and the location.

10) Non-Restrictive Relative Clauses When my father, who risked his life to stand up to extremists, is detained at airports and assumed to be one of them, the road gets longer.

>> Malala's father fights back the extremist.

This utterance was expressed when Malala reminded the audience that the fight for justice and humanity is not over. From her utterance, it can be analyzed as:

When my father, who risked his life to stand up to extremists, is detained at airports and assumed to be one of them, the road gets longer. $\quad(=p)$ Malala's father fought back the extremist. $(=q)$ $\mathrm{p}>\mathrm{q}$

This data was triggered by the nonrestrictive relative clause "who risked his life to stand up to extremists." By this, the listeners assumed that Malala's father fought back the extremist. Through this presupposition, Malala showed that she and her family did not give up easily to fight injustice. They bravely faced the extremist.

The usage of structural presupposition indicators by Malala helped her to communicate something else within one sentence. She applied them to the question and gave additional information within it. What she questioned is mostly related to her personal experience and what the public has been aware of in terms of the world's issues, activity, state, identity, and place. She conveyed the unfair life suffered by some parties in this world. Also, she gave extra information using adverbial clauses and nonrestrictive relative clause indicators. Here, she would like to presuppose that one condition could be accepted to be true over a particular condition in the utterances. The audience or listeners also could catch what was presupposed in the utterance easily since it was stated clearly in the sentence.

\section{The Existence of the Indicators of Non-Factive Presupposition in Malala's Speeches as the Nobel Peace Laureate}

Non-factive presupposition could be recognized by the existence of verbs associated with non-factive such as pretend, think, hope, and others, as Yule (1999) has been proposed. Here, from Malala's four speeches, there were two nonfactive potential presuppositions from the indicator, as table 1 shows.

11) Verbs Associated with Non-Factive When my father, who risked his life to stand up to extremists, is detained at airports and assumed to be one of them, the road gets longer.

>> Malala's father is not an extremist.

This utterance was expressed when Malala reminded the audience that the fight for justice and humanity is not over. From her utterance, it can be analyzed as:

When my father, who risked his life to stand up to extremists, is detained at airports and assumed to be one of them, the road gets longer. $\quad(=p)$

Malala's father is not an extremist. $\quad(=q)$ $p>>$ q

This data was triggered by the verb associated with non-factive "assumed." By this, the listeners assumed that Malala's father is not an extremist. Through this presupposition, Malala would like to convey that there are still people closing their eyes and covering their ears from the truths.

Malala employed some verbs associated with non-factive, such as think, hope, less likely, expect, etc. The existence of these words in Malala's utterances yielded two potential presuppositions; activity and state or condition of something. The potential presuppositions activity mainly tended to talk about actions that 
happened exactly the opposite of what was said. This also occurred with the potential presuppositions state or condition of something where the condition uttered was not fact as Wyse (2009) suggested that predicates that do not establish the statement are known as non-factive. This might be ascribed to Malala's intention for adding a sense of uncertainty or neutrality towards the potential presuppositions within the utterances as Kusumaningroem et al. (2015) have found that United States presidential speeches tended to keep their speech in confusion and vagueness. Here, Malala was found using this type when she was not sure or felt hesitant with the topic she was talking about.

The Existence of the Indicators of Counterfactual Presupposition in Malala's Speeches as the Nobel Peace Laureate

If-clause construction is a conditional sentence in which one half expresses something which depends on the other half. Also, Yule (1999) suggested that what is said is not valid at speaking. Therefore, the writer found out the constructions that bring that meaning into two potential presuppositions, possibilities in the future and an unlikely situation.

12) If-Clause

If all girls went to school for 12 years, low and middle-income countries could add $\$ 92$ billion per year to their economies.

>> Not all girls get 12-years education right now.

This utterance was stated when Malala came up with how to overcome the worlds' problems through the statistic. From her utterance, it can be analyzed as:

If all girls went to school for 12 years, low and middle-income countries could add $\$ 92$ billion per year to their economies. $\quad(=p)$

Not all girls get 12 -years education right now $(=q)$ $\mathrm{p}>\mathrm{q}$

This data was triggered by the ifconditional "if .... could ....". By this, the listeners assumed that not all girls get 12-years education right now. Through this presupposition, Malala would like to emphasize that girls have a big role in the world's stability.
Girls could be the answer to the world's pressing problems. Nevertheless, many girls do not get their rights properly, especially dealing with the education issue. While education is a vital need.

The reason behind this usage might be various. However, the writer believed that Malala applied this construction to communicate what she has been hoping for and her other expectations toward the audience, leaders, and the world for a better life and future.

\section{The Implication of Potential Presupposition Indicators in English Education}

Being aware of presuppositions will help both students and teachers to be a good communicator. This is due to the close relationship between presupposition and communication. Xu \& Luo (2016) proposed that presupposition lies in the interior of the language (including vocabulary, grammar) and the exterior phenomena, such as the subject of communication, language environment, cognition, and others.

In line with English language learning, the potential presuppositions could happen in the daily conversation and even in the class as Tyas, Rukmini, \& Fitriati (2020) have found that presuppositions triggers were used in teacher talk at a higher education institution. This possibly happens between students and teachers. As Sari, Suwandi, \& Slamet (2017) studied how the same presupposition in the interaction among lecturers and students of Indonesian Language education Departments become essential to achieve the goals and create a conducive learning environment. They found out that existential awareness can be manifested in the lectures' comments on the students' performance (in microteaching practices), the lecturers' explanation about the materials, the lecturers' suggestions on learning references, and the lecturers' availability in providing examples. While the factual presupposition also might happen in several contexts, such as apologizing for coming to the class late, giving assessment, answering the questions, explaining the course materials, and etc. 


\section{CONCLUSION}

After analyzing and interpreting the data, the researcher found several conclusions for this study concerning the existence of potential presupposition indicators in Malala's speeches after winning the Nobel Peace Prize. Malala was found using the indicators of six potential presuppositions in her speeches and produced 34 potential presuppositions. The awareness toward these potential presupposition indicators may help us in a communication strategy. In English education, the same presupposition in the interaction among teachers and students is vital to achieve the goals and create a conducive learning environment. Being mindful of those lexical and structures or potential presupposition indicators will help them be good communicators

\section{REFERENCES}

Dabbagh, L. A. (2013). The theatre and presuppositions. Al-Ustath, 2(205), 1-10.

Febrian, R., \& Ardi, H. (2012). An analysis of presupposition used in the novel Harry Potter And The Deathly Hallows. English Language and Literature E-Jornal, 1(1).

Fitri, Y. A., Hamzah, \& Ardi, H. (2012). An analysis of presupposition used in the movie Harry Potter And The Deathly Hallows Part 2. English Language and Literature E-Jornal, 7(6), 1-25.

Geurts, B. (1999). Presuppositions and pronouns. Elsevier Science Ltd.

Khalili, E. (2017). An analysis of presupposition used in The Wrestler. Scinzer Journal of Humanities, 3(2), 83-87.

Kusumaningroem, I., Rukmini, D., \& Yuliasri, I. (2015). Hedges used in the United States presidential speeches. English Education Journal, 5(1), 1-6.

Levinson, S. (1983). Pragmatics. Cambridge University Press.

Liang, R., \& Liu, Y. (2016). An analysis of presupposition triggers in Hilary Clinton's first campaign speech. International Journal of English Linguistics, 6(5), 68-73.
Liang, X., \& Yixue, L. (2016). Presupposition from the perspective of teaching Chinese as a foreign language. 2nd International Conference on Economy, Management and Education Technology, 1352-1355.

Marbun, R. R., Pasaribu, T., \& Pasaribu, D. (2015). An analysis of presupposition on President Barack Obama's Speech on his first and second inaugural addresses. The Episteme Journal of Linguistics and Literature, 1(2).

Mujiyanto, Y. (2011). Nonequivalence in the English-to-Indonesian translation of behavioral clauses. Language Circle - Journal of Language and Literature, 6(1), 57-71.

Mutmainnah, H., \& Sutopo, D. (2016). Spoken text features of the conversation in a TV talk show of Talk Indonesia. Language Circle - Journal of Language and Literature, 11(1), 37-46.

Sari, R. D. P., Suwandi, S., \& Slamet, S. Y. (2017). Factual and existential presuppositions in the interaction among lecturers and students of Indonesian Language Education Department at Universitas Sebelas Maret. Humanus, 16(2), 201-220.

Tyas, U. A. S., Rukmini, D., \& Fitriati, S. W. (2020). Presupposition triggers of teacher talk in a higher education institution. English Education Journal, 10(1), 1-8.

Ulum, M., Sutopo, D., \& Warsono. (2018). A comparison between Trump's and Clinton's commissive speech act in America's presidential campaign speech. English Education Journal, 8(2), 221-228.

Wyse, B. (2009). Factive/non-factive predicate recognition within question generation systems [The Open University]. 